\title{
Inhibition by sodium cromoglycate of bronchoconstriction stimulated by respiratory heat loss: comparison of pressurised aerosol and powder
}

\author{
KM LATIMER, R ROBERTS, MM MORRIS, FE HARGREAVE \\ From the Departments of Medicine, St Joseph's Hospital and McMaster University, and the Department of \\ Clinical Epidemiology and Biostatistics, McMaster University, Hamilton, Ontario, Canada
}

ABSTRACT The protective effect was examined of three doses $(2,10$, and $20 \mathrm{mg}$ ) of sodium cromoglycate inhaled from a pressurised metered dose inhaler on the response to isocapnic hyperventilation of cold dry air in 10 asthmatic subjects. This was compared with the effect of cromoglycate powder $(20 \mathrm{mg})$ inhaled from a Spincap and with placebo given on two occasions. The medications were inhaled on separate days, in random order and with the use of a double blind double dummy technique, 20 minutes before isocapnic hyperventilation of two fold increasing volumes of air $\left(-15^{\circ} \mathrm{C}, 0 \%\right.$ humidity) to produce a $20 \%$ fall in the post-treatment $\mathrm{FEV}_{1}$. The response was expressed as the provocative dose of respiratory heat loss required to cause a fall in $\mathrm{FEV}_{1}$ of $15 \%\left(\mathrm{PD}_{15}, \mathrm{kcal} / \mathrm{min}\right)$. The mean baseline spirometric indices exceeded $85 \%$ of predicted normal values on each test day; both placebo treatments reduced the baseline $\mathrm{FEV}_{1}$ by comparison with all active treatments $(\mathrm{p}<0.0001)$. Comparison of the $\mathrm{PD}_{15}$ on the two placebo days confirmed excellent reproducibility. All doses of cromoglycate shifted the respiratory heat loss dose-response curve to the right of the placebo curve; $\mathrm{PD}_{15}$ after all active treatments exceeded $\mathrm{PD}_{15}$ after placebo $(\mathrm{p}<0 \cdot 0001)$. There was no cromoglycate dose-response relationship between the three doses of aerosol $(p>0.05)$, or between any dose of aerosol and powder ( $p$ $>0.05)$. It is concluded that cromoglycate aerosol inhaled from a pressurised inhaler in a dose of $2 \mathrm{mg}$ gives the same magnitude of protection against bronchoconstriction stimulated by airway cooling as $20 \mathrm{mg}$ of pressurised aerosol or powder from a Spincap.

Pretreatment of the asthmatic airway with inhaled sodium cromoglycate as dry powder, a nebulised solution, and pressurised aerosol can reduce the bronchoconstrictor response to exercise. ${ }^{1-5}$ Similar inhibition has been demonstrated after inhalation of cromoglycate solution $(20 \mathrm{mg})$ and powder (20 $\mathrm{mg}),{ }^{3}$ and after powder $(20 \mathrm{mg})$ and pressurised aerosol $(2 \mathrm{mg}) .^{5}$ The most effective dose of pressurised aerosol has not been established.

Recent work by McFadden and coworkers has identified the importance of airway cooling in the development of exercise stimulated bronchoconstriction and has introduced a thermal challenge using maximal ventilation of cold dry air..$^{6-9} \mathrm{We}$ have modified their method to allow the construc-

Address for reprint requests: Dr FE Hargreave, Firestone Regional Chest and Allergy Unit, St Joseph's Hospital, 50 Charlton Avenue East, Hamilton, Ontario, Canada L8N 1 Y4.

Accepted 7 December 1983 tion of respiratory heat loss dose-response curves and have used it to examine the effect of drugs on bronchoconstriction stimulated by respiratory heat loss. ${ }^{10-13}$

In this study we compared the protective effect of three doses of cromoglycate aerosol $(2,10$, and 20 $\mathrm{mg}$ ) with powder $(20 \mathrm{mg})$ and placebo on the response to respiratory heat loss in 10 adults with asthma, to identify the most effective dose of aerosol.

\section{Methods}

Ten adult asthmatics attending the Firestone regional chest and allergy unit participated in this study (table 1). All had a history of episodic wheeze and dyspnoea and described symptoms of exercise stimulated bronchoconstriction. All were atopic as shown by weal and flare responses to skin prick tests with 
Table 1 Characteristics of the subjects

\begin{tabular}{|c|c|c|c|c|c|}
\hline Subject No & Age $(y)$ & Sex & Height $(\mathrm{cm})$ & Atopy* & Current treatment $\dagger$ \\
\hline $\begin{array}{r}1 \\
2 \\
3 \\
4 \\
5 \\
6 \\
7 \\
8 \\
9 \\
10\end{array}$ & $\begin{array}{l}32 \\
19 \\
25 \\
29 \\
26 \\
22 \\
35 \\
29 \\
25 \\
25\end{array}$ & $\begin{array}{l}\mathbf{M} \\
\mathbf{M} \\
\mathbf{M} \\
\mathbf{F} \\
\mathbf{F} \\
\mathbf{M} \\
\mathbf{M} \\
\mathbf{M} \\
\mathrm{F} \\
\mathbf{F}\end{array}$ & $\begin{array}{l}171 \\
183 \\
173 \\
162 \\
163 \\
173 \\
179 \\
188 \\
166 \\
171\end{array}$ & $\begin{array}{l}6 \\
6 \\
8 \\
4 \\
4 \\
7 \\
6 \\
6 \\
4 \\
5\end{array}$ & $\begin{array}{l}\text { S not daily } \\
\text { S not daily } \\
\text { S 200, T } 200 \\
\text { S } 1000, T 900, \text { B } 400 \\
\text { F } 800, \text { B } 200 \\
\text { S } 400, T 600, \text { B } 200 \\
\text { S } 800 \\
\text { F not daily } \\
\text { S } 400, \text { B } 200 \\
\text { S } 400\end{array}$ \\
\hline
\end{tabular}

*Number of positive weal and flare responses to skinprick tests with 16 common allergen extracts.

tS - salbutamol $(\mu \mathrm{g})$; B-beclomethasone dipropionate $(\mu \mathrm{g})$; F-fenoterol (total dose per day, $\mu \mathrm{g})$, T-slow release theophylline (total dose per day, $\mathrm{mg}$ ).

16 common allergen extracts. Over the period of the study, symptoms of asthma did not disturb sleep and the baseline $\mathrm{FEV}_{1}$ before delivery of any test medication exceeded $70 \%$ of predicted normal. No subject had experienced symptoms of respiratory infection or been exposed to a sensitising allergen (with the exception of regular exposure to house dust in subjects 3 and 5-10) in the month preceding the study. The study was approved by the hospital research committee and each subject gave written informed consent.

Each subject attended the laboratory at the same time of day on six test days within three weeks. Aerosol bronchodilator treatment was withheld for six hours and theophylline for 36 hours, but the use of beclomethasone was not interrupted; no subject used cromoglycate for control of asthma. After a 15 minute rest three measurements of $\mathrm{FEV}_{1}$ spaced one minute apart were made with a 9 litre Collins water spirometer. The test medications were then given double blind in random order. They were: 1-placebo aerosol (four puffs), placebo powder; 2-placebo aerosol (four puffs), placebo powder; 3-cromoglycate aerosol (two puffs, $1 \mathrm{mg} / \mathrm{puff}$ ), placebo aerosol (2 puffs), placebo powder; 4 cromoglycate aerosol (two puffs, $5 \mathrm{mg} /$ puff), placebo aerosol (two puffs), placebo powder; 5cromoglycate aerosol (4 puffs, $5 \mathrm{mg} /$ puff), placebo powder; 6-placebo aerosol (four puffs), cromoglycate powder $(20 \mathrm{mg})$. Aerosols were inhaled from pressurised metered dose canisters and powder from a capsule (Spincap) placed in an inhaling device (Spinhaler). All medications were given in a standardised manner. The subject exhaled to near functional residual capacity (FRC), and the pressurised canister was positioned $3 \mathrm{~cm}$ from the wide open mouth and activated once by the experimenter just after the beginning of a slow inhalation to near total lung capacity (TLC). The subject then held his breath for 10 seconds. The remaining three inhalations were delivered consecutively by the same technique. Finally, the subject exhaled to near FRC and, holding the Spinhaler between the lips, quickly inhaled to near TLC and again held his breath for 10 seconds. Twenty minutes later the $F E V_{1}$ was remeasured three times, and isocapnic hyperventilation of subfreezing dry air was begun.

Isocapnic hyperventilation was carried out by the method used by O'Byrne et al,,$^{10}$ which was a modification of that described by Strauss et al. ${ }^{7}$ Cold dry air $\left(-15^{\circ} \mathrm{C}, 0 \%\right.$ relative humidity), generated by a heat exchanger, was inhaled in twofold increasing volumes $(7 \cdot 5,15,30$, and $60 \mathrm{l} / \mathrm{min}$ and at maximum voluntary ventilation) for three minutes at intervals of five minutes. Carbon dioxide was added to the inhaled air to keep the subject eucapnic during each period of hyperventilation. The response was measured by the change in $\mathrm{FEV}_{1}$ from the lowest post-treatment value to the lowest value recorded 0.5 and 1.5 minutes after each inhalation. If there was a fall in FEV, the measurement was repeated at three minutes and at subsequent two minute intervals until the lowest value was recorded. Once the $\mathrm{FEV}_{1}$ started to improve the subject received the next inhalation of cold air. Inhalations were discontinued once the $\mathrm{FEV}_{1}$, had fallen by $20 \%$ or after maximum voluntary ventilation. The final level of hyperventilation was completed no later than 70 minutes after delivery of the pretreatment for all subjects on all test days. The respiratory heat loss (RHL, $\mathrm{kcal} / \mathrm{min}$ ) was calculated for each level of ventilation from the formula $\mathrm{RHL}=\dot{\mathrm{V}} \mathrm{E}(\mathrm{HC}[\mathrm{Ti}-$ $\left.\mathrm{Te}]+\mathrm{HV}\left[\mathrm{WC}_{\mathrm{i}}-\mathrm{WC}_{\mathrm{e}}\right]\right)$, where $\dot{\mathrm{VE}}=$ minute ventilation $(1 / \mathrm{min}), \mathrm{HC} \stackrel{\mathrm{m}}{=}$ heat capacity of air $(0.000304 \mathrm{kcal} / \mathrm{min}), \mathrm{Ti}=$ inspired air temperature $\left({ }^{\circ} \mathrm{C}\right), \mathrm{Te}=$ expired air temperature $\left({ }^{\circ} \mathrm{C}\right), \mathrm{HV}=$ latent heat of vaporisation of water $(0.00058 \mathrm{kcal} /$ $\mathrm{mg}), \mathrm{WC}_{\mathrm{i}}=$ water content of inspired air $(\mathrm{mg} / \mathrm{l})$, and $\mathrm{WC}_{\mathrm{e}}=$ water content of expired air $(\mathrm{mg} / \mathrm{l})$. Fast responding thermistors placed within the mouthpiece recorded $\mathrm{Ti}$ and $\mathrm{Te}$. The inspired air was dry. Expired air was assumed to be fully 
saturated at the expired temperature, ${ }^{14}$ and the water content was obtained from standard saturation temperature relationships. ${ }^{15}$ For each test condition dose-response curves were constructed with $\mathrm{FEV}_{1}$ (percentage change from the lowest post-treatment value) on the ordinate and respiratory heat loss $(\mathrm{kcal} / \mathrm{min})$ expressed logarithmically on the abscissa. The provocative concentration of respiratory heat loss causing a $15 \%$ fall in $\mathrm{FEV}_{1}\left(\mathrm{PD}_{15}, \mathrm{kcal} / \mathrm{min}\right)$ was obtained from the $\log$ dose-response curves by linear interpolation of the points above and below the $15 \%$ fall in $\mathrm{FEV}_{1}$.

In this experiment each subject was studied on six occasions, twice after placebo and four times after active treatment, in random order. The data for each outcome, percentage change in $\mathrm{FEV}_{1}$ after treatment and $P D_{15}$, therefore formed a randomised block design ${ }^{16}$ with the subjects as "blocks." The appropriate approach for comparing treatments was thus two way analysis of variance, which resulted in an $F$ test of the difference between the six treatment means. Rather than conducting a large number of comparisons between pairs of treatments, the technique of linear contrasts ${ }^{17}$ was used $(a)$ to compare the mean after placebo with the mean after each active treatment, $(b)$ to test the degree of any treatment dose-response correlation within the three doses of aerosol, and $(c)$ to compare the effect of the $20 \mathrm{mg}$ aerosol and powder treatments. Analysis of covariance $^{18}$ was used to determine whether the observed treatment effects on $P_{15}$ could be explained solely by a change in airway calibre.

The reliability of $P D_{15}$ was examined by estimation of the within subject and between subject components of variance from a one way analysis of variance of the results from the two tests after placebo.
Reproducibility was quantified by the within subject standard deviation of $\mathrm{PD}_{15}$. The intraclass correlation, the ratio of between subject variance to the sum of between subject plus within subject variance, was used as a reliability coefficient. The intraclass correlation is the proportion of total variance due to real differences between subjects and can be thought of as a signal to noise ratio-or, more exactly, a signal to signal plus noise ratio. ${ }^{19}$

\section{Results}

The mean pretreatment $\mathrm{FEV}_{1}$ on the six treatment days showed only slight variation (table 2 ) that was clearly non-significant ( $p=0.45)$. Inhalation of all test medications produced a small reduction in mean $\mathrm{FEV}_{1}$. This effect was greater after the two placebo treatments (mean $4.7 \%$ ) than after the four cromoglycate treatments (mean $2.3 \%$ ). This difference, although small, was highly significant $(p<0.0001)$. There is little evidence of any real differences in mean reduction in $F E V_{1}$ after the four individual cromoglycate treatments $(p>0 \cdot 05)$.

There was a shift to the right in the respiratory heat loss dose-response curves after all cromoglycate treatments by comparison with placebo (fig). The mean $\mathrm{PD}_{15}$ after placebo was $1.62 \mathrm{kcal}(6.78$ $\mathrm{kJ}) / \mathrm{min}$, compared with the mean after all cromoglycate treatments of $1.99 \mathrm{kcal}(8.33 \mathrm{~kJ}) / \mathrm{min}(\mathrm{p}<$ $0 \cdot 0001)$. The mean $\mathrm{PD}_{15}$ values after individual cromoglycate treatments (table 2 ) were very similar; the test for trend with dose among the aerosol groups showed this to be non-significant ( $p>0.5)$, and similarly with the comparison between the 20 $\mathrm{mg}$ dose of aerosol and powder $(p>0.5)$. The effect of the post-treatment $\mathrm{FEV}_{1}$ on $\mathrm{PD}_{15}$ was examined

Table 2 Effects of placebo and sodium cromoglycate on response to respiratory heat loss

\begin{tabular}{|c|c|c|c|c|c|c|c|c|c|c|c|c|c|c|c|c|c|c|}
\hline \multirow[t]{2}{*}{$\begin{array}{l}\text { Subject } \\
\text { No }\end{array}$} & \multicolumn{3}{|c|}{ Placebo } & \multicolumn{3}{|c|}{ Placebo } & \multicolumn{3}{|c|}{$\begin{array}{l}\text { Aerosol cromoglycate } \\
2 \mathrm{mg}\end{array}$} & \multicolumn{3}{|c|}{$\begin{array}{l}\text { Aerosol cromoglycate } \\
10 \mathrm{mg}\end{array}$} & \multicolumn{3}{|c|}{$\begin{array}{l}\text { Aerosol cromoglycate } \\
20 \mathrm{mg}\end{array}$} & \multicolumn{3}{|c|}{$\begin{array}{l}\text { Powder cromoglycate } \\
20 \mathrm{mg}\end{array}$} \\
\hline & $\begin{array}{l}\text { FEV } \\
(\% \\
\text { pred) }\end{array}$ & $\begin{array}{l}\% \Delta \\
F E V_{1}^{*}\end{array}$ & $P D_{15}^{\dagger}$ & $\mathrm{FEV}_{1}$ & $\begin{array}{l}\% \Delta \\
F E V_{1}^{*}\end{array}$ & $P D_{15}^{\dagger}$ & $F E V_{1}$ & $\stackrel{\% \Delta}{F E V_{1}^{*}}$ & $P D_{15}^{\dagger}$ & $F E V_{1}$ & $\begin{array}{l}\% \Delta \\
F E V_{1}^{*}\end{array}$ & $P D_{15}^{\dagger}$ & $F E V_{1}$ & ${ }_{F E V_{1}^{*}}^{*}$ & $P D_{15}^{\dagger}$ & $F E V_{1}$ & $\begin{array}{l}\% \Delta \\
F E V_{1}^{*}\end{array}$ & $P D_{15}^{\dagger}$ \\
\hline $\begin{array}{l}1 \\
2 \\
3 \\
4 \\
5 \\
6 \\
7 \\
8 \\
9 \\
0\end{array}$ & $\begin{array}{r}85.2 \\
90.1 \\
88.0 \\
94.6 \\
105.4 \\
73.9 \\
83.6 \\
73.0 \\
107.8 \\
83.5\end{array}$ & $\begin{array}{l}-5.2 \\
-5.9 \\
-4.4 \\
-5.1 \\
-4.3 \\
-\quad 9.2 \\
=13.2 \\
=1.9 \\
=7.7 \\
-\quad 2.6\end{array}$ & $\begin{array}{l}2.04 \\
1.92 \\
1.67 \\
1.22 \\
2.11 \\
1.13 \\
1.86 \\
1.88 \\
1.27 \\
1.31\end{array}$ & $\begin{array}{r}85 \cdot 2 \\
87.5 \\
83.4 \\
94 \cdot 3 \\
106.0 \\
71.7 \\
86.7 \\
72.1 \\
109.2 \\
93.3\end{array}$ & $\begin{array}{r}-1.8 \\
0.5 \\
-5.2 \\
-9.5 \\
-1.9 \\
-0.6 \\
-4.8 \\
-1.7 \\
-4.7 \\
-5.3\end{array}$ & $\begin{array}{l}2.22 \\
1.81 \\
1.41 \\
1.04 \\
1.80 \\
1.16 \\
2.05 \\
1.91 \\
1.13 \\
1.33\end{array}$ & $\begin{array}{r}85.9 \\
86 \cdot 2 \\
82.1 \\
99.5 \\
103.5 \\
69.1 \\
80 \cdot 8 \\
75.2 \\
113.5 \\
77.5\end{array}$ & $\begin{array}{r}-2.3 \\
3.3 \\
-1.4 \\
-9.9 \\
0.6 \\
-0.6 \\
1.4 \\
-1.4 \\
0 \\
-1.0\end{array}$ & $\begin{array}{r}2.47 \\
2.54 \\
>2.43 \\
1.20 \\
2.98 \\
1.37 \\
2.12 \\
1.92 \\
1.66 \\
1.26\end{array}$ & $\begin{array}{r}82.7 \\
89.0 \\
82 \cdot 1 \\
108 \cdot 5 \\
107.0 \\
70 \cdot 2 \\
86 \cdot 8 \\
72 \cdot 8 \\
109.7 \\
80.4\end{array}$ & $\begin{array}{r}-2.9 \\
-1.6 \\
-3.1 \\
-1.7 \\
-3.1 \\
-1.3 \\
-2.1 \\
0.3 \\
-0.8\end{array}$ & $\begin{array}{r}2.33 \\
2.15 \\
2.10 \\
1.89 \\
>2.70 \\
1.27 \\
2.71 \\
1.94 \\
1.65 \\
1.20\end{array}$ & $\begin{array}{r}79.8 \\
88.4 \\
86.4 \\
99.4 \\
106.0 \\
72.3 \\
85.5 \\
72.3 \\
106 \\
79.8\end{array}$ & $\begin{array}{r}-1.5 \\
-0.7 \\
-3.5 \\
-4.9 \\
0 \\
-5.9 \\
-4.8 \\
0.5 \\
-6.3 \\
1.7\end{array}$ & $\begin{array}{l}2 . \\
2 . \\
1 . \\
1 . \\
2 . \\
1 . \\
2 . \\
1 . \\
1 . \\
1 .\end{array}$ & $\begin{array}{r}78.1 \\
91.7 \\
83.4 \\
104.0 \\
103.7 \\
70.9 \\
84.2 \\
74.1 \\
110.8 \\
95.2\end{array}$ & $\begin{array}{l}-4 \\
-2 \\
-2 \\
-4 \\
-0 \\
-3 \\
-3 \\
-6 \\
-2\end{array}$ & $\begin{array}{r}>2.53 \\
>2.58 \\
2.17 \\
1.43 \\
2.16 \\
1.19 \\
2.23 \\
1.84 \\
1.72 \\
1.56\end{array}$ \\
\hline $\begin{array}{c}\text { Mean } \\
\text { D }\end{array}$ & $\begin{array}{l}88.5 \\
11.6\end{array}$ & $\begin{array}{r}-6.0 \\
3.3\end{array}$ & $\begin{array}{l}1.64 \\
0.37\end{array}$ & 88.9 & $\begin{array}{r}-3 \cdot 5 \\
3 \cdot 0\end{array}$ & $\begin{array}{l}1.59 \\
0.42\end{array}$ & & $\begin{array}{r}-1 \cdot 1 \\
3 \cdot 5\end{array}$ & $\begin{array}{l}2.00 \\
0.62\end{array}$ & $\begin{array}{l}88.9 \\
14.6\end{array}$ & $\begin{array}{r}-1 \cdot 7 \\
1.1\end{array}$ & $\begin{array}{l}1.99 \\
0.52\end{array}$ & $\begin{array}{l}87 \cdot 6 \\
12 \cdot 5\end{array}$ & $\begin{array}{r}-2.5 \\
2.9\end{array}$ & $\begin{array}{l}2.01 \\
0.58\end{array}$ & & $\begin{array}{r}-3.6 \\
1.7\end{array}$ & $\begin{array}{l}1.94 \\
0.47\end{array}$ \\
\hline
\end{tabular}

Percentage change in FEV, 20 minutes after medication.

Provocative dose of respiratory heat loss producing a $15 \%$ fall in $\mathrm{FEV}_{1}$, expressed in $\mathrm{kcal} / \mathrm{min}(1 \mathrm{kcal}=4 \cdot 184 \mathrm{~kJ})$.

$o$ pred-percentage of predicted normal. ${ }^{20}$ 


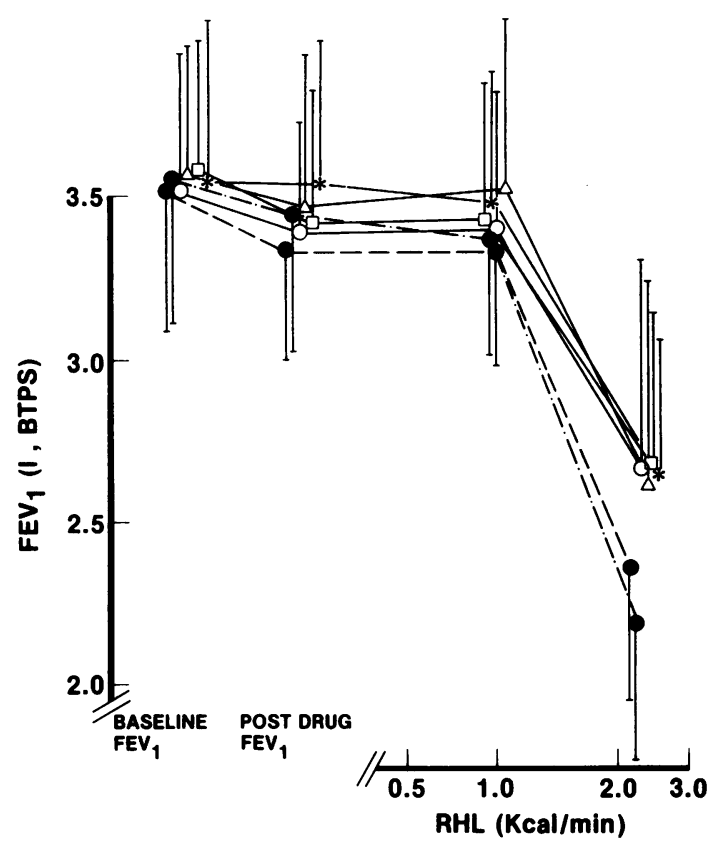

Dose-response curves showing the relationship between respiratory heat loss $(R H L)$ and $F E V$, after pretreatment with placebo (O- - - - $-\mathrm{O}$ and $\mathrm{O}-\ldots-\mathrm{O})$, cromoglycate aerosol $(2 \mathrm{mg}(\mathrm{O}), 10 \mathrm{mg}(\triangle)$, and $20 \mathrm{mg}$ (प)), and cromoglycate powder $\left(20 \mathrm{mg},{ }^{*}\right)$. Each point represents the mean for 10 subjects and the bars represent one standard deviation above and below the mean. Conversion: Traditional to SI units - heat: $1 \mathrm{kcal}=4 \cdot 184$ $k J$.

by analysis of covariance, the $\mathrm{FEV}_{1}$ being used as a covariate. This left the mean $P_{15}$ almost unchanged, so the differences in $\mathrm{PD}_{15}$ after placebo and after cromoglycate treatments could not be explained as due to the difference in $\mathrm{FEV}_{1}$.

The within subject standard deviation of $\mathrm{PD}_{15}$ was $0.12 \mathrm{kcal}(0.50 \mathrm{~kJ}) / \mathrm{min}$, which indicates that a within subject change of $0.35 \mathrm{kcal}(1.46 \mathrm{~kJ}) / \mathrm{min}$ or more would be unlikely to be due to measurement variability. Furthermore, the intraclass correlation for $\mathrm{PD}_{15}$ was $0.91(\mathrm{p}<0.0001)$, indicating good reliability when measurement variation is compared with true between subject differences.

\section{Discussion}

This study is the first to examine the protective effect of sodium cromoglycate aerosol inhaled from a pressurised inhaler on the response to hyperventilation of cold air. The results show that the lower dose of $2 \mathrm{mg}$ is more effective than placebo and is as effective as the higher doses of 10 and $20 \mathrm{mg}$.

The effectiveness of cromoglycate powder in a dose of $40 \mathrm{mg}$ on bronchoconstriction stimulated by $\overrightarrow{\vec{F}}$ hyperventilation of cold air has been observed in earlier studies..$^{21-23}$ In the present study $20 \mathrm{mg}$ of powder was found to be as effective as $2 \mathrm{mg}$ of pressurised aerosol. This is similar to the effect on bronchoconstriction stimulated by treadmill running. ${ }^{5}$

The observation that the protective effect of pres- is surised aerosol was not dose related is at variance $\overrightarrow{0}$ with the dose-response effect of cromoglycate nebuliser solution on exercise stimulated bronchoconstriction found by Patel et al. ${ }^{24}$ Patel observed increasing protection when estimated doses of 2.4 , 12 , and $24 \mathrm{mg}$ were generated continuously by a $\omega_{0}$ Wright nebuliser and inhaled by tidal breathing over 5 minutes, and no greater protection after inhalation of $48 \mathrm{mg}$. Presumably the differences between the two studies are due to differences in the doses or $\frac{}{2}$ distribution (or both) of cromoglycate deposited in the lung by the different methods of aerosol generation and inhalation. In our study the $2 \mathrm{mg}$ dose of pressurised aerosol might have deposited an effec- $\vec{\oplus}$

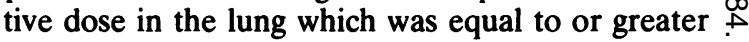

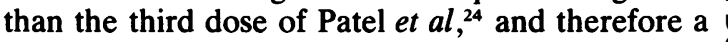
higher dose would not have a greater effect. Alternatively, the different results between the two studies may be due to the different methods used to stimulate bronchoconstriction.

Two conflicting theories are currently held about the pathogenesis of exercise stimulated bronchoconstriction. Deal and coworkers ${ }^{25}$ concluded from a series of experiments using isocapnic hyperventilation of cold air that the major stimulus for exercise triggered bronchoconstriction was airway cooling without the release of chemical mediators. The alternative theory, proposed by Ben-Dov and his colleagues, ${ }^{26}$ suggests that exercise stimulated bron- 3 choconstriction is primarily temperature indepen- $\dot{\delta}$ dent and caused by mediator release. Recent $₹$ findings by Lee and colleagues ${ }^{27}$ that mediator $O$ release does occur with respiratory heat loss, regardless of whether the cooling is achieved by exercise or by hyperventilation, incorporates aspects of both theories and is in keeping with the idea the cromo- $\sigma$ glycate attenuates bronchoconstriction provoked by $N$ both exercise and respiratory heat loss through its $\underset{\mathrm{N}}{\mathrm{N}}$ mast cell stabilising properties.

In practical terms, the results of this study and that of Bundgaard et al ${ }^{5}$ suggest that bronchocon- $\frac{\stackrel{C}{\Phi}}{\mathscr{D}}$ striction stimulated by cold air or by exercise will be $\stackrel{?}{?}$ equally inhibited by $2 \mathrm{mg}$ of cromoglycate aerosol $T$ inhaled from a pressurised inhaler and by $20 \mathrm{mg}$ of powder from a Spincap.

We thank the patients who participated in this study and Fisons Pharmaceuticals for the grant that supported it. 


\section{References}

${ }^{1}$ Poppius H, Muittari A, Kreus K-E, Korhonen O, Viljanen A. Exercise asthma and disodium cromoglycate. Br Med J 1970;iv:337-9.

${ }^{2}$ Eggleston PA, Bierman CW, Pierson WE, Stamm SJ, Van Arsdel PP jun. A double blind trial of the effect of cromolyn sodium on exercise-induced bronchospasm. J Allergy Clin Immunol 1972;50:57-63.

${ }^{3}$ Dahl R, Henriksen JM. Inhibition of exercise-induced bronchoconstriction by nebulised sodium cromoglycate in patients with bronchial asthma. Scand J Respir Dis 1979;60:51-5.

${ }^{4}$ Sanguinetti CM, Gasparini S, Bonifazi F, Vennarucci LS. Exercise-induced asthma diagnosis and prevention with a metered dose aerosol formulation of sodium cromoglycate. Respiration 1982;43:132-41.

${ }^{5}$ Bundgaard A, Bach-Mortensen N, Schmidt A. The effect of sodium cromoglycate delivered by Spinhaler and by pressurized aerosol on exercise-induced asthma in children. Clin Allergy 1982;12:601-5.

${ }^{6}$ Strauss RH, McFadden ER jun, Ingram RH jun, Jaeger JJ. Enhancement of exercise-induced asthma by cold air. N Engl J Med 1977;297:743-7.

7 Strauss RH, McFadden ER jun, Ingram RH jun, Deal EC jun, Jaeger JJ. Influence of heat and humidity on the airway obstruction induced by exercise in asthma. $J$ Clin Invest 1978;61:433-40.

${ }^{8}$ Deal EC jun, McFadden ER jun, Ingram RH jun, Strauss RH, Jaeger JJ. Role of respiratory heat exchange in production of exercise-induced asthma. $J$ Appl Physiol: Respirat Environ Exercise Physiol 1979;46:467-75.

${ }^{9}$ Deal EC jun, McFadden ER jun, Ingram RH jun, Jaeger JJ. Hyperpnea and heat flux: initial reaction sequence in exercise-induced asthma. J Appl Physiol: Respirat Environ Exercise Physiol 1979;46:476-83.

${ }^{10}$ O'Byrne PM, Ryan G, Morris M, et al. Asthma induced by cold air and its relation to nonspecific bronchial responsiveness to methacholine. Am Rev Respir Dis 1982;125:281-5.

" O'Byrne PM, Morris M, Roberts R, Hargreave FE. Inhibition of the bronchial response to respiratory heat exchange by increasing doses of terbutaline sulphate. Thorax 1982;37:913-7.

12 Latimer KM, O'Byrne PM, Morris MM, Roberts R, Hargreave FE. Bronchoconstriction stimulated by airway cooling: better protection with combined inhalation of terbutaline sulphate and cromolyn sodium than with either alone. Am Rev Respir Dis 1983;128:440-3.
${ }^{13}$ O'Byrne PM, Thomson NC, Morris M, Roberts RS, Daniel EE, Hargreave FE. The protective effect of inhaled chlorpheniramine and atropine on bronchoconstriction stimulated by airway cooling. $\mathrm{Am} \mathrm{Rev}$ Respir Dis 1983;128:611-7.

14 Ferrus L, Guenard H, Vardon G, Varene P. Respiratory water loss. Respir Physiol 1980;39:367-81.

is Weast RC. Handbook of chemistry and physics. 58th ed. Cleveland, Ohio: Chemical Rubber, 1977:E-41.

${ }^{16}$ Kleinbaum DG, Kupper LL. Applied regression analysis and other multivariable methods. Massachusetts: North Scituate, Duxbury Press, 1978:289-309.

${ }^{17}$ Kleinbaum DG, Kupper LL. Applied regression analysis and other multivariable methods. Massachusetts: North Scituate, Duxbury Press, 1978:277-88.

${ }^{18}$ Kleinbaum DG, Kupper LL. Applied regression analysis and other multivariable methods. Massachusetts: North Scituate, Duxbury Press, 1978:209-15.

${ }^{19}$ Winer BJ. Statistical principles in experimental design. New York: McGraw-Hill, 1971:244-314.

${ }^{20}$ Crapo RO, Morris AH, Gardner RM. Reference spirometric values using techniques and equipment that meet ATS recommendations. Am Rev Respir Dis 1981;123:659-64.

${ }^{21}$ Breslin FJ, McFadden ER jun, Ingram RH jun. The effects of cromolyn sodium on the airway response to hyperpnea and cold air in asthma. Am Rev Respir Dis 1980;122:11-6.

${ }^{22}$ Fanta $\mathrm{CH}$, McFadden ER jun, Ingram RH jun. Effects of cromolyn sodium on the response to respiratory heat loss in normal subjects. Am Rev Respir Dis 1981;123:161-4.

${ }^{23}$ Griffin MP, MacDonald N, McFadden ER jun. Shortand long-term effects of cromolyn sodium on the airway reactivity of asthmatics. $J$ Allergy Clin Imunol 1983;71:331-8.

${ }^{24}$ Patel KR, Berkin KE, Kerr JW. Dose-response study of sodium cromoglycate in exercise-induced asthma. Thorax 1982;37:663-6.

${ }^{25}$ Deal EC jun, Wasserman SI, Soter NA, Ingram RH jun, McFadden ER jun. Evaluation of role played by mediators of immediate hypersensitivity in exerciseinduced asthma. J Clin Invest 1980;65:659-65.

${ }^{26}$ Ben-Dov I, Bar-Yishay E, Godfrey S. Refractory period after exercise-induced asthma unexplained by respiratory heat loss. Am Rev Respir Dis 1982;125:530-4.

${ }^{27}$ Lee TH, Assoufi BK, Kay AB. The link between exercise, respiratory heat exchange, and the mast cell in bronchial asthma. Lancet $1983 ; \mathrm{i}: 520-2$. 